\title{
Biological Activity Assessment in Mexican Tropical Soils with Different Hydrocarbon Contamination Histories
}

\author{
Jessica Riveroll-Larios • Erika Escalante-Espinosa • \\ Reyna L. Fócil-Monterrubio • \\ Ildefonso J. Díaz-Ramírez
}

Received: 14 June 2015 / Accepted: 7 September 2015 /Published online: 29 September 2015

(C) The Author(s) 2015. This article is published with open access at Springerlink.com

\begin{abstract}
The use of soil health indicators linked to microbial activities, such as key enzymes and respirometric profiles, helps assess the natural attenuation potential of soils contaminated with hydrocarbons. In this study, the intrinsic physicochemical characteristics, biological activity and biodegradation potential were recorded for two soils with different contamination histories ( $>5$ years and $<1$ months). The enzymatic activity (lipase and dehydrogenase) as well as microbiological and mineralisation profiles were measured in contaminated soil samples. Soil suspensions were tested as microbial inocula in biodegradation potential assays using contaminated perlite as an inert support. The basal respiratory rate of the recently contaminated soil was 15 $38 \mathrm{mg} \mathrm{C}-\mathrm{CO}_{2} \mathrm{~kg}^{-1} \mathrm{~h}^{-1}$, while the weathered soil presented a greater basal mineralisation capacity of 55-70 mg $\mathrm{C}-\mathrm{CO}_{2} \mathrm{~kg}^{-1} \mathrm{~h}^{-1}$. The basal levels of lipase and dehydrogenase were significantly greater than those recorded in non-contaminated soils $\left(551 \pm 21 \mu \mathrm{g} \mathrm{pNP} \mathrm{g}^{-1}\right)$. Regarding the biodegradation potential assessment, the lipase (1000-3000 $\mu \mathrm{g} \mathrm{pNP} \mathrm{g}^{-1}$ of perlite) and
\end{abstract}

J. Riveroll-Larios · E. Escalante-Espinosa •

R. L. Fócil-Monterrubio • I. J. Díaz-Ramírez $(\bowtie)$

Academic Division of Biological Sciences, Academic Group of Evaluation and Environmental Technology, Laboratory of

Bioprocess, Juárez Autonomous University of Tabasco, Edif. H.

Km 0.5 Carr. Villahermosa - Cárdenas, Villahermosa, Tabasco

C.P. 86039 , México

e-mail: idrxanum@gmail.com

I. J. Díaz-Ramírez

e-mail: ildefonso.diaz@ujat.mx dehydrogenase ( $\sim 3000 \mu \mathrm{g}$ INF $\mathrm{g}^{-1}$ of perlite) activities in the inoculum of the recently contaminated soil were greater than those recorded in the inoculum of the weathered soil. This was correlated with a high mineralisation rate $\left(\sim 30 \mathrm{mg} \mathrm{C}-\mathrm{CO}_{2} \mathrm{~kg}^{-1} \mathrm{~h}^{-1}\right)$ in the recently contaminated soil and a reduction in hydrocarbon concentration $(\sim 30 \%)$. The combination of an inert support and enzymatic and respirometric analyses made it possible to detect the different biodegradation capacities of the studied inocula and the natural attenuation potential of a recently contaminated soil at high hydrocarbon concentrations.

Keywords Lipase - Dehydrogenase - Biodegradation . Natural attenuation

\section{Introduction}

Petroleum industry activities such as drilling, transportation and refining in Mexico take place mostly in the southeastern region of the country. Several oil fields are located in the state of Tabasco, where the tropical soils present a variety of edaphic and ecological characteristics (Adams et al. 2009; Díaz-Ramírez et al. 2013). Documented oil spills in this region have affected large areas of soil, rivers, streams and lagoons. Some of these spills occurred more than 20 years ago, but others are much more recent (Adams et al. 2012; Cram et al. 2004; Gallegos Martínez et al. 2000). Recently, contaminated sites are reclaimed by applying active bioremediation strategies, such as land farming, 
biostimulation-bioaugmentation, biopiles and soil washing with biosurfactants (Medina-Moreno et al. 2011; Vyas and Dave 2011), as an immediate response to the environmental emergencies caused by oil spills. In contrast, if the presence of hydrocarbons and the environmental conditions (flood-drought cycles, extreme temperatures, leaching and increased solar radiation) result in a weathered contaminated soil, in which the residual hydrocarbons are more complex, recalcitrant and less bioavailable to the native microbial populations (Maletić et al. 2011). In these cases, passive methods (natural attenuation, phytoremediation, biostabilisation) are viable alternatives for the selfrecovery of the sites, especially those with a high ecological and agricultural value (Adams et al. 2011). Usually, physicochemical parameters are used (organic matter, nutrient balance, water retention capacity, repellency, etc.) to asses soil quality and establish a remediation end point (Adams et al. 2008); however, as they change slowly, long periods are required to identify significant changes. Other important criteria when selecting remediation technologies and carrying out monitoring in the field, due to their quick response, are the microbial activity levels in response to the presence of hydrocarbons and the weather conditions that prevail at a site (Margesin et al. 2007; Riffaldi et al. 2006). Biological indicators such as the type and number of predominant microorganisms, enzymatic activities (dehydrogenases, lipases, oxygenases) and degradation kinetics (measured in the field or the laboratory), as well as the half-life of the contaminants, have been analysed successfully in order to determine the level of microbial activity in contaminated soils, to evaluate the biodegradation of the contaminants by the microbial community and to determine the resulting benefits after treating the soil (Liu et al. 2011; Chang et al. 2010; Bending et al. 2004). Data from microbial activities and biodegrading potential, related to contamination soil histories, are relevant because they are useful to diagnose bioremediation feasibility and to determine end points after remediation strategies. Our aim was to evaluate biological indicator levels and the biodegradation potential of native microbial inocula in tropical soils with different hydrocarbon contamination histories. The analysis was based on the enzymatic activity (lipase and dehydrogenase) and respirometric profiles (mineralisation) recorded throughout biodegradation assays carried out under non-limiting hydrocarbon availability conditions.

\section{Materials and Methods}

\subsection{Study Area}

The study area is located in the state of Tabasco, southeastern Mexico. The contaminated sites are adjacent to facilities with oil activities. The first site is located in Villa La Venta, near a petroleum refining facility, with clay soil and mangrove vegetation, where hydrocarbon spills have historically occurred (Pérez-Cadena 2010). The second, a recently contaminated site ( $<1$ month), is located in the Samaria-Luna oil extraction field, in the Cunduacán municipality. The sites were selected based on a comparative analysis of the type and concentration of contaminants, time of contamination, actual state of the contaminated sites, access availability to the sites, vegetation and the presence of water bodies.

\subsection{Soil Sampling}

Soil samples were collected with a hand auger and spatula, following the Mexican regulations as technical guideline (NOM-138-SEMARNAT/SS-2003). The sampling points were selected considering the level of contamination and the characteristics of the soil after a visual inspection. Four samples were collected at the weathered site and three samples at the recently contaminated site. Three types of samples were collected at both sites: (a) for a physicochemical analysis $(2.5 \mathrm{~kg}$ soil) in black plastic bags (hydrocarbon content), (b) for microbiological and enzymatic analyses (200 g soil) in glass bottles with a Teflon septa, and (c) for biodegradation assays ( $2 \mathrm{~kg}$ soil) in black plastic bags. Samples were collected from two strata: $0-10 \mathrm{~cm}$ and $10-45 \mathrm{~cm}$. Once labelled and registered, the samples for the microbiological analyses and the enzymatic activity quantification were transported (at room temperature) to the Bioprocess Laboratory for processing. The samples for the enzyme determination were kept at room temperature in order to minimise disruption of the natural activity of the native microorganisms. Before carrying out the corresponding analyses, the moist soils were sieved $(4.7 \mathrm{~mm})$ to remove stones and plant debris (roots), and to homogenise the particle size.

\subsection{Media Culture and Support (Perlite)}

Biodegradation assays and microbial recording were carried out in a mineral base medium (MBM1) with 
the following composition $\left(\mathrm{g} \mathrm{l}^{-1}\right)$ : $3.0 \mathrm{NaNO}_{3}, 0.30$ $\mathrm{MgSO}_{4} \cdot 7 \mathrm{H}_{2} \mathrm{O}, 0.50 \mathrm{KCl}, 13.0 \mathrm{KH}_{2} \mathrm{PO}_{4}$ and 1.0 $\mathrm{K}_{2} \mathrm{HPO}_{4}$. To this was added $\mathrm{Na}_{4} \mathrm{P}_{2} \mathrm{O}_{7} \cdot 10 \mathrm{H}_{2} \mathrm{O}(1.80 \mathrm{~g})$ to prepare the soil suspension (microbial inocula, MBM2). Both media were adjusted to $\mathrm{pH} 6$ with $2 \mathrm{~N}$ $\mathrm{NaOH}$ (Díaz-Ramírez et al. 2008).

The biodegradation assays were carried out using perlite as a support and light Olmeca Crude Oil as a carbon source. The perlite was sieved $(2.8 \mathrm{~mm})$, washed thrice with hot distilled water $\left(60{ }^{\circ} \mathrm{C}\right)$ and dried in an oven at $105{ }^{\circ} \mathrm{C}$ for 48 h. The Olmeca Crude Oil was heated to eliminate volatile compounds (5 days at $70{ }^{\circ} \mathrm{C}$ ). Oilspiking was later carried out under manual mixing, using $n$-hexane as a carrier. The resulting support was allowed to evaporate under a fume hood for $48 \mathrm{~h}$.

\subsection{Basal Activity in the Soil}

The soil samples were manually mixed and stored to be analysed $48 \mathrm{~h}$ after sampling. The following physicochemical parameters were recorded: (a) $\mathrm{pH}$, (b) conductivity $\left(\mathrm{dS} \mathrm{m} \mathrm{m}^{-1}\right.$ ), (c) humidity (\%) and (d) total hydrocarbon content (mg TPH kg-1). All samples used for the analyses were previously dried. At the same time, the following biological and microbiological indicators were analysed: (a) basal respiration ( $\mathrm{mg} \mathrm{C}-\mathrm{CO}_{2} \mathrm{~kg} 24 \mathrm{~h}^{-1}$ ), (b) lipase enzymatic activity ( $\mu \mathrm{g}$ pNP kg $10 \mathrm{~min}^{-1}$ ), (c) dehydrogenase enzymatic activity ( $\mu \mathrm{g}$ INF $\mathrm{kg}^{-1}$ day $^{-1}$ ), (d) microbial total count (CFU g $\mathrm{g}^{-1}$ ) and (e) hydrocarbon-degrading microorganisms according to the MPN method (cell number $\mathrm{g}^{-1}$ ).

\subsection{Biodegradation Potential Assays with Differently Contaminated Soils}

\subsubsection{Soil Suspension Preparation}

Recently contaminated soil (RCSS) and weathered soil (WSS) suspensions were prepared by stirring (4 h) contaminated soil samples (100 g dry weight) in flasks containing $750 \mathrm{ml}$ of MBM2 at $30{ }^{\circ} \mathrm{C}$. Volumes of $15 \mathrm{ml}$ of the resulting soil suspensions were transferred to the experimental units containing perlite for the biodegradation assays.

\subsubsection{Biodegradation Assays}

Biodegradation kinetic assays were carried out following a completely randomised experimental design with the factors: (a) inoculum source (RCSS and WSS), (b) hydrocarbon concentration $(10,000$ and $20,000 \mathrm{mg}$ $\mathrm{kg}^{-1}$, and a non-contaminated control) and (c) incubation time. Each experimental unit ( $500 \mathrm{ml}$ glass bottles) contained perlite $(10.2 \mathrm{~g})$, MBM1 $(10 \mathrm{ml})$, sterile distilled water $(5 \mathrm{ml})$ and $\mathrm{SS}$ as the inoculum $(15 \mathrm{ml})$. The experiment setting comprised a group of 15 bottles, separated into five bottles per treatment. Nine bottles were connected to a SS4 respirometry system to continuously analyse the produced $\mathrm{CO}_{2}$. The remaining six bottles were incubated under similar conditions (water bath at $35^{\circ} \mathrm{C}$ ) for 30 days. In order to maintain the field capacity of the perlite around $60 \%$, the water lost by natural evaporation was replaced every week.

One bottle per treatment was selected for sampling every 7 days during the incubation period to determine the lipase and dehydrogenase enzymatic activities. Samples were subdivided to obtain nine sub-samples per treatment $(0.5 \mathrm{~g})$. The variables evaluated throughout the experiment were (a) lipase and dehydrogenase enzymatic activity, (b) biodegradation, (c) produced $\mathrm{CO}_{2}$ and (d) initial and final total microbial count (CFU g ${ }^{-1}$ of perlite).

\subsection{Hydrocarbon Analyses}

The residual hydrocarbon content was gravimetrically measured after its extraction from the solid samples following the Soxhlet method (EPA 3540 method; NOM-138-SEMARNAT/SS-2003) and using a mixture of acetone/hexane $(1: 1)$ as solvent. Oil concentrates were recovered after solvent separation using a rotary evaporator (Büchi model R-210).

\subsection{Respirometric Analyses}

A respirometric system was used (Sable Systems SS4 ${ }^{\circledR}$ ) in order to record the production of $\mathrm{CO}_{2}$ throughout the biodegradation assays. The system was designed as a pushed open system with a mass flow control valve and automated sampling. The system makes it possible to record $\mathrm{CO}_{2}$ at different recording cycles according to the culture stage $(4,6,8,12$ and $24 \mathrm{~h})$. The sensor base line was adjusted to zero with a $\mathrm{CO}_{2}$-free air inlet after every recording cycle. The raw data of the produced $\mathrm{CO}_{2}$ of all 
the samples were transformed to obtain volumetric data $\left(\mathrm{ml} \mathrm{min}{ }^{-1}\right)$ and, later, mass units ( $\mathrm{mg} \mathrm{C}-\mathrm{CO}_{2} \mathrm{~kg}^{-1}$ perlite) using the ExpeData software (Sable Intl. Co.). Finally, the accumulated produced $\mathrm{CO}_{2}$ and the production rates $\left(\mathrm{mg} \mathrm{C}-\mathrm{CO}_{2} \mathrm{~kg}^{-1}\right.$ perlite $\left.\mathrm{h}^{-1}\right)$ were calculated from the raw data.

\subsection{Enzymatic Analyses}

\subsubsection{Dehydrogenase}

The method for measuring DHS activity was adapted from those proposed by Von Mersi and Schinner (1991) and Neto et al. (2007). Iodo-nitro-tetrazolium (5 mM INT) was used as electron acceptor in the presence of Tris buffer (1 M, pH 7) in each soil or perlite sample. The produced red formazan was extracted with acetone (Baker) from the samples after being incubated for $24 \mathrm{~h}$ at $30{ }^{\circ} \mathrm{C}$. It was later quantified spectrophotometrically $(\lambda=493 \mathrm{~nm})$ using a standard curve at different concentrations $\left(5,10,15,20,25,30\right.$ and $35 \mu \mathrm{g} \mathrm{INF} \mathrm{ml} \mathrm{m}^{-1}$ acetone). When necessary, samples were diluted with acetone.

\subsubsection{Lipase}

Lipase activity was recorded following the method proposed by Margesin (2005). Soil samples were incubated in the presence of $p$-nitrophenyl-butyrate (pNPB) as substrate and a phosphate buffer solution ( $\mathrm{pH} 7)$. The produced $p$-nitro-phenol was spectrophotometrically quantified $(\lambda=400 \mathrm{~nm})$ using a standard curve at different concentrations $(0,25,50,75,100$ and $125 \mu \mathrm{g}$ pNP $5 \mathrm{ml}^{-1}$ buffer solution). When necessary, samples were diluted with the same buffer.

\subsection{Microbial Analyses}

Total counts of the bacterial and fungal populations were recorded following Lorch et al. (1995) on trypticasein soy agar (TSA; Bioxon, Mexico) and potato dextrose agar (PDA; Bioxon, Mexico), respectively. Cultures were incubated at $30{ }^{\circ} \mathrm{C}$ and counts were carried out after incubation periods of 2 days (bacterial) and 3 to 5 days (fungal). The number of microorganisms able to grow in TPH $\left(500 \mathrm{mg} \mathrm{l}^{-1}\right)$ as the sole carbon source was assessed by the most probable number (MPN) method, based on the procedure reported by Wrenn and Venosa (1996). The samples were incubated for 2 weeks at $30{ }^{\circ} \mathrm{C}$. Later, iodo-nitrotetrazolium (Sigma Chemical Co., St. Louis, Mo.) at $535 \mu \mathrm{g} \mathrm{ml}^{-1}$ was used as an indicator. The number of hydrocarbon degrading microorganisms was calculated using the MPN-calculator (EPA V 4.04).

\subsection{Statistical Analyses}

The recorded variables were analysed statistically with the Stat Graphics 5.1 software package. An analysis of variance (ANOVA) was carried out for the basal assays. A multivariate ANOVA was carried out for both the enzymatic and respirometric activities to determine differences between treatments (hydrocarbon concentration) and inocula (different contamination history).

\section{Results and Discussion}

\subsection{Hydrocarbon Contaminated Soil Characterisation} (Physicochemical and Biological Soil Characterisations)

\subsubsection{Weathered Soil}

Three sampling areas were selected near the refining facilities in La Venta: (a) a vegetated flooded area, (b) the wall of a drain facing a mangrove forest and (c) a highly contaminated area adjacent to the drain. Three soil samples were collected and physicochemically characterised (Table 1). The soils at these sites presented a visual and textural aspect typical of weathered hydrocarbon contaminated soils (dark colour, intense oil smell, sticky consistency). They were classified as strongly acidic $(\mathrm{pH} 3.9-5.2)$ and slightly saline (0.92 to $1.56 \mathrm{dS} \mathrm{m}^{-1}$ ). The organic matter in the soils was three times greater than the recently contaminated soil, possibly resulting from the abundant vegetation and the frequent crude oil inputs. However, other parameters associated with soil fertility, including cationic exchange capacity (Table 1) and salinity, indicated the adverse effects of the complex and high molecular weight hydrocarbons. Previous studies on this type of soil have reported a high repellency and a loss of water retention capacity (Adams et al. 2008). Most of the weathered soils presented a texture corresponding to sandy-loam (81-85\% sand content), except for sample SLV-P9M9 which was clay-loam and was collected at a contaminated point adjacent to the mangrove forest near 
Table 1 Recently contaminated soil and weathered soil characterisation

\begin{tabular}{|c|c|c|c|c|c|c|c|c|c|c|c|c|c|}
\hline Soil ID & $\begin{array}{l}\mathrm{SOM}^{\mathrm{a}} \\
\%\end{array}$ & $\begin{array}{l}\mathrm{N}_{\mathrm{t}} \\
\mathrm{mg} \mathrm{kg}^{-1}\end{array}$ & P Olsen & $\mathrm{K}$ & $\mathrm{Ca}$ & $\begin{array}{l}\mathrm{Mg} \\
\mathrm{cmol} \mathrm{kg}^{-1}\end{array}$ & $\mathrm{Na}$ & $\mathrm{CEC}^{\mathrm{b}}$ & $\begin{array}{l}\mathrm{TPH}^{\mathrm{c}} \\
\mathrm{mg} \mathrm{kg}^{-1}\end{array}$ & Clay & $\begin{array}{l}\text { Silt } \\
\%\end{array}$ & Sand & Textural class \\
\hline \multicolumn{14}{|c|}{ Recently contaminated soil } \\
\hline SSL-C1 & 8.67 & 0.17 & 1.59 & 0.02 & ND & 1.28 & 1.33 & 29.74 & $17,207 \pm 204$ & 72 & 13 & 15 & Clayed \\
\hline SSL-C2 & 4.67 & 0.12 & 0.87 & 0.02 & ND & 5.44 & 6.98 & 27.06 & $20,395 \pm 315$ & 63 & 10 & 27 & Clayed \\
\hline SSL-C3 & 5.5 & 0.26 & 12.4 & 0.08 & 1.45 & 6.17 & 0.53 & 28.28 & $12,211 \pm 192$ & 62 & 31 & 7 & Clayed \\
\hline \multicolumn{14}{|c|}{ Weathered soil } \\
\hline SLV-P1M1 & 27.67 & 0.29 & 32.8 & 0.02 & ND & 2.40 & 9.29 & 8.29 & $77,098 \pm 638$ & 10 & 9 & 81 & Sandy-loam \\
\hline SLV-P1M3 & 23.67 & 0.20 & 41.4 & 0.02 & ND & 2.34 & 8.95 & 7.31 & $64,548 \pm 523$ & 10 & 7 & 83 & Sandy-loam \\
\hline SLV-P7M7 & 17.17 & 0.20 & 19 & 0.01 & ND & 1.87 & 8.81 & 4.88 & $37,735 \pm 702$ & 8 & 7 & 85 & Sandy-loam \\
\hline SLV-P9M9 & 14.34 & 0.34 & 6.67 & 0.06 & 2.62 & 10.02 & 21.83 & 22.43 & $55,670 \pm 603$ & 34 & 33 & 33 & Clay-loam \\
\hline
\end{tabular}

The TPH content and the physicochemical characteristics were recorded following Mexican regulations as guidelines (NOM-138SEMARNAT/SS-2003; NOM-021-RECNAT-2000)

$N D$ not detected (below the detection limit)

${ }^{\text {a }}$ Soil organic matter recorded following the Walkley and Black method (NOM-021-RECNAT-2000)

${ }^{\mathrm{b}}$ Cation exchange capacity

${ }^{\mathrm{c}}$ Total petroleum hydrocarbon

the drain. The TPH content $\left(\sim 77,000 \mathrm{mg} \mathrm{kg}^{-1}\right)$ recorded in the weathered soil samples was greater than the concentration $\left(\sim 20,000 \mathrm{mg} \mathrm{kg}^{-1}\right)$ registered in the recently contaminated soil samples. Soil samples collected from areas with similar environmental and geomorphological conditions (high TPH levels, flooded clay soils) have been studied previously (Adams et al. 2009; Cram et al. 2004; Gallegos Martínez et al. 2000; Zavala et al. 2005).

\subsubsection{Recently Contaminated Soil}

Recently contaminated soil was collected 1 month after a major oil spill (Olmeca crude oil). Four sampling areas were selected: (a) an oil-impregnated pasture where spilled oil accumulated, (b) the containment wall near a non-contaminated area, (c) a point near the access to the site where oil accumulated and (d) a point adjacent to the pipeline (drain) on a sandy shore. Nine soil samples were collected and characterised. All samples had a neutral $\mathrm{pH}(\sim 7.04-7.92)$ and an average conductivity characteristic of non-saline soils $\left(\sim 0.65 \mathrm{dS} \mathrm{m}^{-1}\right)$. The resulting SOM (soil organic matter) and CEC (cation exchange capacity) corresponded to soils used for cattle grazing and grassland soil health. The soil texture analysis classified it as sandy-loam. Considering the short time between the spill and the sampling, it is likely that these soil properties, at the time, still remain without major alterations.

\subsection{Basal Biological Activity}

The effect of the hydrocarbon contamination history on the microbial activity in the soil was evaluated. The analyses were based on the microbial composition and the quantification of the enzymatic (lipase and dehydrogenase) and respirometric (background) activities in recently contaminated and weathered soil samples. The resulting profiles were used to select the soil inocula used for assaying the biodegradation potential of these soils under non-bioavailability limitations.

\subsubsection{Heterotrophic and Hydrocarbon-Degrading Microorganisms}

Soil samples from the two contaminated sites were microbiologically characterised following conventional methods. The results are presented in Table 2. The bacterial counts in the weathered soil samples growing on TSA were greater $\left(1.2-23 \times 10^{7} \mathrm{CFU} \mathrm{g}^{-1}\right)$ than those recorded in the recently contaminated soil samples $\left(\sim 1.2 \times 10^{7} \mathrm{UFC}^{-1}\right)$. The fungal counts growing on PDA were twice smaller than the bacterial numbers and were similar in both types of soil $\left(\sim 0.21-4.8 \times 10^{5}\right.$ $\left.\mathrm{CFU} \mathrm{g}{ }^{-1}\right)$. The hydrocarbon-degrading microbial counts 
Table 2 Total counts of bacterial and fungal populations and TPH degrading microorganisms count for the recently contaminated soil and weathered soil samples

\begin{tabular}{|c|c|c|c|}
\hline \multirow[t]{2}{*}{ Soil sample } & \multicolumn{2}{|c|}{ Total bacterial count ${ }^{\mathrm{a}}$} & \multirow{2}{*}{$\begin{array}{l}\begin{array}{l}\text { Degrading-hydrocarbons } \\
\text { microorganism count }\end{array} \\
\text { Cell number } \times 10^{6} \mathrm{~g}^{-1}\end{array}$} \\
\hline & $\begin{array}{l}\text { Bacteria } \\
\mathrm{CFU} \times 10^{7} \mathrm{~g}^{-1}\end{array}$ & $\begin{array}{l}\text { Fungi } \\
\text { CFU } \times 10^{5} \mathrm{~g}^{-1}\end{array}$ & \\
\hline \multicolumn{4}{|c|}{ Recently contaminated soil } \\
\hline SSL-1 & $>10.00$ & $>10.00$ & 24.20 \\
\hline SSL-2 & $1.16 \pm 0.01$ & 4.83. \pm 0.25 & 946.72 \\
\hline SSL-3 & $1.20 \pm 0.01$ & $0.88 \pm 0.01$ & 123.92 \\
\hline \multicolumn{4}{|c|}{ Weathered soil } \\
\hline SLV1 & $0.10 \pm 0.01$ & $0.78 \pm 0.01$ & 1.10 \\
\hline SLV2 & $0.13 \pm 0.01$ & $0.26 \pm 0.00^{\mathrm{c}}$ & 0.72 \\
\hline SLV3 & $1.22 \pm 0.38$ & $0.21 \pm 0.00^{\mathrm{c}}$ & 49.62 \\
\hline SLV4 & $13.30 \pm 2.50$ & $2.00 \pm 0.02$ & 10.32 \\
\hline SLV5 & $23.00 \pm 0.25$ & $3.83 \pm 0.00^{\mathrm{c}}$ & $4,409.96$ \\
\hline SLV6 & $0.46 \pm 0.00^{\mathrm{c}}$ & $0.45 \pm 0.00^{\mathrm{c}}$ & $\mathrm{ND}^{\mathrm{d}}$ \\
\hline
\end{tabular}

${ }^{\text {a }}$ Values obtained for three replicates per dilution. Counts greater than $10 \times 10^{7}$ are indicated as $>10.0$

${ }^{\mathrm{b}}$ Values were calculated using the MPN Calculator software, version 4.04 (Klee 1996. EPA)

${ }^{\mathrm{c}}$ Standard deviation $<0.003$

${ }^{\mathrm{d}}$ Non-determined soil sample

were greater in the weathered soil $\left(5 \times 10^{7}-4.4 \times 10^{9}\right.$ cell $\mathrm{g}^{-1}$ of soil) than in the recently contaminated soil $(0.2-$ $9.4 \times 10^{8}$ cell g $^{-1}$ soil) (Table 2 ).

\subsubsection{Soil Respirometry}

In order to assess the intrinsic respiratory activity in several soil samples, the production of $\mathrm{CO}_{2}$ under controlled conditions was recorded during a 24-h kinetic cycle. The resulting $\mathrm{CO}_{2}$ production rate profiles are presented in Fig. 1a and b. Samples from the recently contaminated soil presented similar profiles with an average of $20 \mathrm{mg} \mathrm{C}-\mathrm{CO}_{2} \mathrm{~kg}^{-1} \mathrm{~h}^{-1}$ (Fig. 1a). The controlled soil respiration assay indicated that the maximum production rates for most of the samples were registered after $8 \mathrm{~h}$ and remained throughout the time window analysis.

The maximum $\mathrm{CO}_{2}$ production rate of $38 \mathrm{mg} \mathrm{C}-\mathrm{CO}_{2}$ $\mathrm{kg}^{-1} \mathrm{~h}^{-1}$ was recorded for sample SSL4 (Fig. 1a). For the weathered soil, the $\mathrm{CO}_{2}$ production rates were markedly different among the samples (Fig. 1b). The greatest average $\mathrm{CO}_{2}$ production rates were recorded for samples SLV4 and SLV5, ranging from 55 to $70 \mathrm{mg} \mathrm{C}-\mathrm{CO}_{2} \mathrm{~kg}^{-1}$ $\mathrm{h}^{-1}$. In contrast, the basal soil respiration in a noncontaminated soil collected near the contaminated site varied from 1.02 to $1.08 \mathrm{mg} \mathrm{C}-\mathrm{CO}_{2} \mathrm{~kg}^{-1} \mathrm{~h}^{-1}$. GuzmánOsorio (2011) reported a basal soil respiration of $1.4 \mathrm{mg}$ $\mathrm{C}-\mathrm{CO}_{2} \mathrm{~kg}^{-1} \mathrm{~h}^{-1}$ for soil in a flooded pasture in the southeastern region of the state of Veracruz (near the contaminated site in Tabasco). Similar results were obtained by Sánchez et al. (2005) of around $1.9 \mathrm{mg} \mathrm{C}-\mathrm{CO}_{2}$ $\mathrm{kg}^{-1} \mathrm{~h}^{-1}$ for soil in a tropical savannah.

For sample SLV5, the level of $\mathrm{CO}_{2}$ production (68.38 mg C- $-\mathrm{CO}_{2} \mathrm{~kg}^{-1} \mathrm{~h}^{-1}$ ) was positively correlated with the high hydrocarbon-degrading number (Table 2), reaching a maximum activity $21 \mathrm{~h}$ after the assay started. Soil respiration and nutrient and microorganism content have been used to estimate biological activity in the presence of organic pollutants, such as petroleum hydrocarbons (Supaphol et al. 2005). The respirometric results were used as background mineralisation (basal respiration) to select the soil samples most suitable for the biodegradation potential assessment.

\subsubsection{Lipase and Dehydrogenase Enzymatic Activity}

Lipase Lipase activity in the soil was recorded in all the samples collected from the different contaminated sites. The results may be seen in Fig. $2 a$ and $b$. The greatest lipase activity was recorded in sample SSL3 (1477.5 mg 

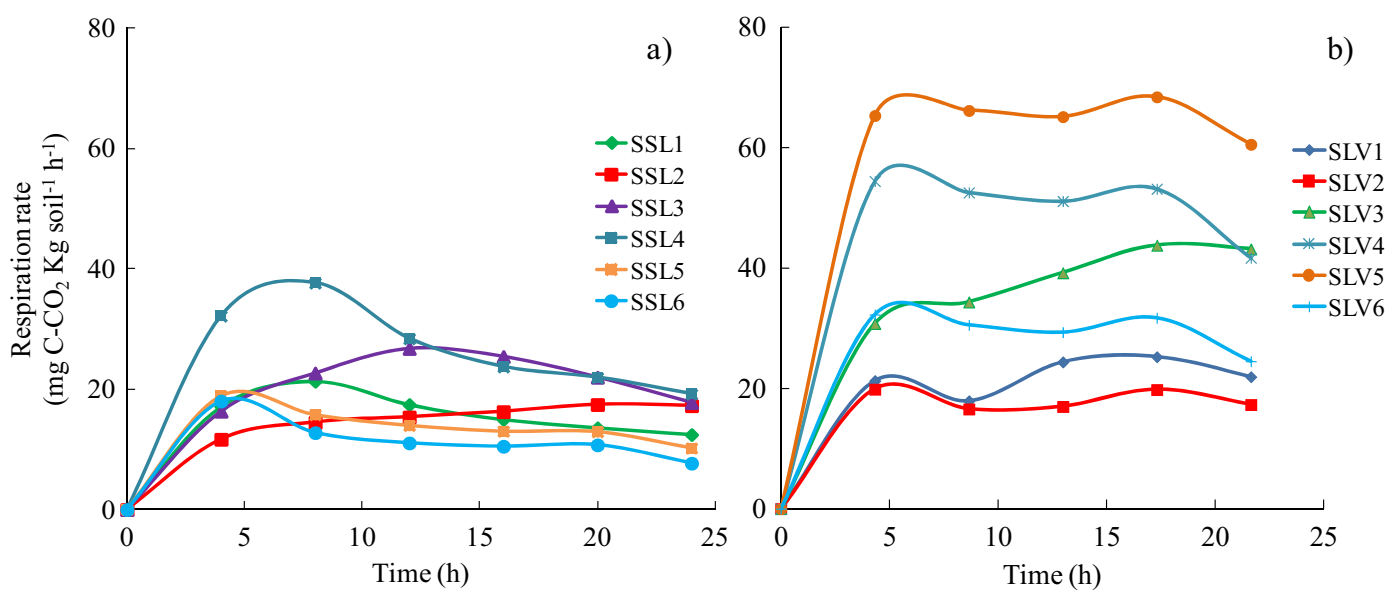

Fig. $1 \mathrm{CO}_{2}$ production rate (mg C-CO $\left.\mathrm{Cg}^{-1} \mathrm{~h}^{-1}\right)$ in samples of a recently contaminated soils and b weathered soils. The values were obtained during a 24-h kinetic cycle

pNP g ${ }^{-1} 10 \mathrm{~min}^{-1}$ ) (Fig. 2a), followed by sample SSL4 (996.0 $\mathrm{mg} \mathrm{pNP}^{-1} 10 \mathrm{~min}^{-1}$ ). Statistical analyses showed significant differences $(p<0.05)$ between the most active samples and the other recently contaminated

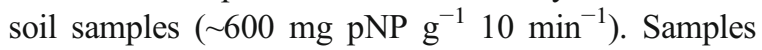
from the non-contaminated soil adjacent to the contaminated site presented a lipase activity of $531.2 \pm 37.4 \mathrm{mg}$ $\mathrm{pNP} \mathrm{g}^{-1} 10 \mathrm{~min}^{-1}$. These results reflect the induction of the lipases due to the presence of the TPH mixture, composed mostly of $n$-alkanes of medium carbon chain, which are easily assimilated by soil microorganisms that produce metabolites that provide a substrate for microbial hydrolases. Additionally, the high levels of lipase activity in the recently contaminated soils agree with the respiration rates (Fig. 1a) measured in the short test for the corresponding samples (i.e. SSL3 and SSL4).

Regarding the weathered soil samples (Fig. 2b), two samples (SLV2 and SLV6) presented the greatest lipase activity with values of 1200 to $1461.02 \mathrm{mg} \mathrm{pNP} \mathrm{g}^{-1}$ $10 \mathrm{~min}^{-1}$. Significantly lower lipase activity values (500 to $700 \mathrm{mg} \mathrm{pNP} \mathrm{g}^{-1} 10 \mathrm{~min}^{-1}$ ) were recorded in most of the weathered soil samples (Fig. 2b).

Lipase activity in most of the samples from the two sites was above $500 \mu \mathrm{g} \mathrm{pNP} \mathrm{g}{ }^{-1} 10 \mathrm{~min}^{-1}$, which is considerably greater than the values reported for most contaminated soils. Díaz-Ramírez et al. (2010) studied the effect of hydrocarbon concentration on microbial activity through the application of different bioremediation treatments, and recorded average lipase values below $400 \mu \mathrm{g} \mathrm{pNP} \mathrm{g}{ }^{-1} 10 \mathrm{~min}^{-1}$ for biostimulated soils $\left(10,000 \mathrm{mg} \mathrm{kg}^{-1}\right)$ and around $240 \mu \mathrm{g} \mathrm{pNP} \mathrm{g}^{-1} 10 \mathrm{~min}^{-1}$ for non-contaminated clay-loam soil, after 30 days of treatment. In general, the lipase enzyme has been used as a biological indicator for hydrocarbon biodegradation as it initiates lipid decomposition (glycerol ester hydrolases), which acts on the carboxyl ester bondings in acylglycerol to produce a release of fatty acids and glycerol (Margesin et al. 2007; Riffaldi et al. 2006; Sirisha et al. 2010). Lipases have broad substrate specificity and are active throughout a wide range of temperatures. They are involved in diverse biotechnological applications because of their biocatalytic versatility (Hasan et al. 2009; Joseph et al. 2008).

Dehydrogenase Dehydrogenase activity was recorded in the same soil samples collected at the recently contaminated site and the weathered site (results in Fig. 2c and d). For the recently contaminated soils, the greatest dehydrogenase activity was recorded in sample SSL2 $\left(\sim 125,560.7 \mu \mathrm{g} \mathrm{INF} \mathrm{g}^{-1}\right.$ soil $\left.24 \mathrm{~h}^{-1}\right)$ (Fig. 2c), followed by samples SSL3 and SSL5 $(80,000$ to $100,000 \mu \mathrm{g}$ INF $\mathrm{g}^{-1}$ soil $24 \mathrm{~h}^{-1}$ ). These dehydrogenase levels were significantly greater than those recorded in samples SSL1, SSL6 and SSL7. In contrast, the weathered soils presented a maximum dehydrogenase activity of 46,800 to $61,450 \mu \mathrm{g}$ of INF $\mathrm{g}^{-1}$ of soil after $24 \mathrm{~h}$ of incubation (SLV1, SLV2, SLV5 and SLV7). However, the dehydrogenase activity values of both soils indicate a high oxidative microbial metabolism. The higher DHS values observed in the recently contaminated soil (Fig. 2) may be attributed to the presence of easily biodegradable compounds like $n$-alkanes (C10-C21) and low molecular weight aromatic compounds which 

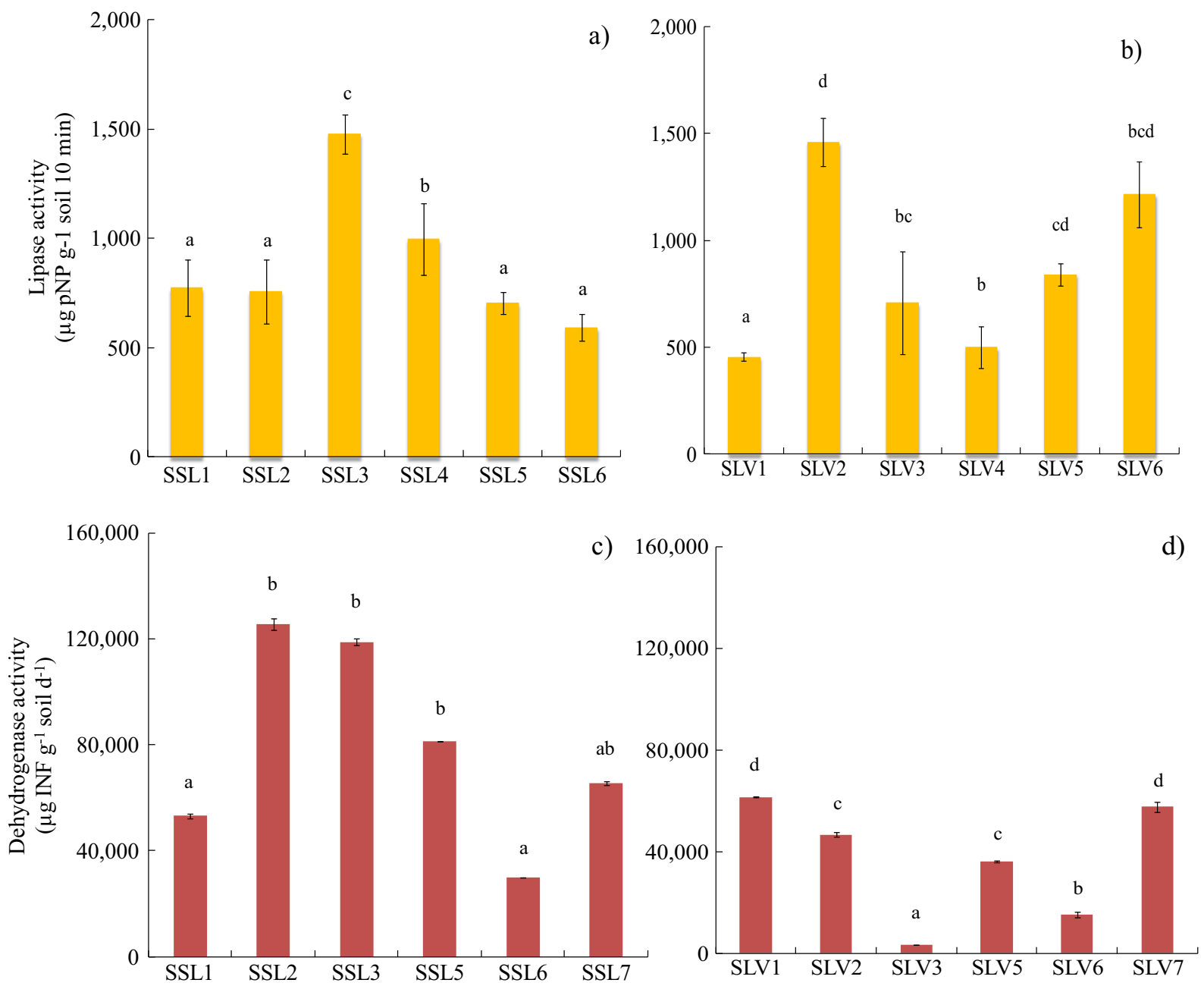

Fig. 2 Lipase ( $\mu \mathrm{g} \mathrm{pNP} \mathrm{g}{ }^{-1}$ soil $\left.10 \mathrm{~min}^{-1}\right)$ and dehydrogenase ( $\mu \mathrm{g}$ INF $\mathrm{g}^{-1}$ soil $24 \mathrm{~h}^{-1}$ ) activities recorded in a lipase in recently contaminated soil, b lipase in weathered soil, c dehydrogenase in recently contaminated soil and dehydrogenase in

are the main component of the light crude oil spilled at the site. In contrast, in the weathered soil the residual hydrocarbon is composed mostly of more recalcitrant fractions (Acosta and Paolini 2005; Gallegos Martínez et al. 2000). Mirás Avalos et al. (2007) found a strong positive correlation between dehydrogenase (DHS) and respiratory activity $\left(\mathrm{CO}_{2}\right.$ production), used as microbial activity indicators in eroded soils. These results are similar to those obtained for the hydrocarboncontaminated soils collected in the present study at the highly contaminated site at La Venta. The soil respiration recorded in sample SLV6 was $68.38 \mathrm{mg} \mathrm{C}-\mathrm{CO}_{2}$ $\mathrm{kg}^{-1} \mathrm{~h}^{-1}$, which corresponds to one of the higher DHS weathered soil. The error bars represent the standard deviation of three replicates. The letters $a, b, c$ and $d$ indicate the statistical difference among samples

activities and could be associated with a high degradingmicroorganism number in this sample (Table 2).

\subsection{Biodegradation Potential Assays}

A biodegradation assay was designed to determine the biodegradation efficiency of the microbial community composing the soil inocula obtained from the two sites with different contamination histories. The assay was carried out using perlite as an artificially contaminated support $\left(\sim 10,000\right.$ and $\left.20,000 \mathrm{mg} \mathrm{kg}^{-1}\right)$ to simulate non-bioavailability hydrocarbon limiting conditions. The recorded biological indicators were the 
lipase and dehydrogenase activities, along with respirometric profiles (evolved $\mathrm{CO}_{2}$ ) in response to high hydrocarbon concentrations.

\subsubsection{Lipase Activity}

The lipase activity recorded in the recently contaminated soil (RCSS) and the weathered soil (WSS) suspensions is shown in Fig. 3a and b. The lipase activity in the RCSS increased with respect to the hydrocarbon con-

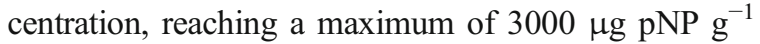
perlite in $20,000 \mathrm{mg} \mathrm{kg}^{-1}$ of hydrocarbons, and $2700 \mu \mathrm{g}$ pNP $\mathrm{g}^{-1}$ perlite in $10,000 \mathrm{mg} \mathrm{kg}^{-1}$ of hydrocarbons (Fig. 3a). The greatest values were recorded during the first 7 days of the culture in all the treatments. After this period, the lipase activity decreased to around $1400 \mu \mathrm{g}$ pNP $\mathrm{g}^{-1}$ perlite for both hydrocarbon concentrations. The lipase activity in the WSS increased gradually up to a maximum at day 7 (Fig. 3b), with slightly greater values in the lower hydrocarbon concentration $\left(\sim 1400 \mu \mathrm{g} \mathrm{pNP} \mathrm{g}^{-1}\right.$ perlite) than those recorded in the higher concentration. After this period, the lipase activity increased throughout the assay to reach another maximum at day 21 of incubation (Fig. 3b), with values of $2362.42 \pm 277$ and $1753.01 \pm 96 \mu \mathrm{g} \mathrm{pNP} \mathrm{g}^{-1}$ perlite in 10,000 and $20,000 \mathrm{mg} \mathrm{kg}^{-1}$ of hydrocarbons, respectively. The lipase activity was significantly greater when the RCSS was used as the inoculum than when the WSS was used. The lipase activity in the control bottles (noncontaminated perlite) was lower than that recorded in the treatments with hydrocarbons and in those inoculated with RCSS and WSS (Fig. 3a, b). Statistical analyses of the enzyme activity values, using a Kruskal-Wallis test, revealed significant differences $(p<0.05)$ between the inocula (RCSS and WSS) and between the contaminated and non-contaminated perlite in each assay.

Lipase activity that responds to the presence of hydrocarbons during different bioremediation treatments has been studied (Maila and Cloete 2005; Margesin and Schinner 2001; Margesin et al. 2007), and stable values have been recorded even with low rates of hydrocarbon biodegradation. Margesin et al. (2000) reported low levels and a fast decrease in lipase activity throughout the monitoring time in a field study of aged biodiesel contaminated soils. The composition and recalcitrance of the residual compounds were identified as factors that may influence lipase activity in aged contaminated soils. Nonetheless, the monitoring of lipase activity has been successfully used as a biological indicator. In a study of soils with different TPH concentrations and input of nutrients, Margesin et al. (2007) reported a parallel behaviour between TPH removal and lipase activity, indicating an increase in the enzyme together with an increase in hydrocarbon loading rates. Lipase activity behaves similarly under non-limiting bioavailability conditions, such as those established in the present study, with high levels in contaminated perlite and in the inocula obtained from both the recently contaminated soil and the weathered soil. A negative correlation between enzyme activity and TPH content was recorded in all the treatments, indicating that the greatest lipase activity coincided with the lowest hydrocarbon content. The induction of the enzyme has been proposed (Margesin 2005) and may respond to the presence of hydrocarbon biodegradation sub-products, which are substrates for lipases. This enzymatic response makes it possible to detect the high hydrocarbon-biodegrading capacity of the microbial community present in the recently contaminated soil.

\subsubsection{Dehydrogenase Activity}

The dehydrogenase activity recorded throughout the biodegradation potential assays for the RCSS and WSS suspensions is presented in Fig. 3c and $d$. Dehydrogenase levels in the presence of the RCSS inoculum increased during the first 7 days of the culture, reaching a maximum of $3390 \mu \mathrm{g} \mathrm{INF} \mathrm{g}{ }^{-1}$ perlite $24 \mathrm{~h}^{-1}$ in $10,000 \mathrm{mg} \mathrm{kg}^{-1}$ of perlite (Fig. 3c) and $2560 \mu \mathrm{g} \mathrm{INF}$ $\mathrm{g}^{-1}$ perlite $24 \mathrm{~h}^{-1}$ in $20,000 \mathrm{mg} \mathrm{kg}^{-1}$ of perlite in the experimental bottles. Background levels of the enzyme (non-contaminated control) were significantly lower (708-1500 $\mu \mathrm{g} \mathrm{INF} \mathrm{g}^{-1}$ perlite $24 \mathrm{~h}^{-1}$ ) than those recorded in the contaminated perlite (Fig. 3c), probably due to the presence of residual organic matter and hydrocarbons in the soil suspensions used as inocula.

The dehydrogenase activity in the perlite inoculated with the WSS inoculum is presented in Fig. 3d. The enzymatic activity remained below $1000 \mu \mathrm{g}$ INF $\mathrm{g}^{-1}$ perlite $24 \mathrm{~h}^{-1}$ in all the treatments. The maximum activity $\left(\sim 800 \mu \mathrm{g} \mathrm{INF} \mathrm{g} \mathrm{g}^{-1}\right.$ perlite $\left.24 \mathrm{~h}^{-1}\right)$ was recorded in the contaminated perlite with $20,000 \mathrm{mg} \mathrm{kg}^{-1}$ after 15 days (Fig. 3d). In general, the dehydrogenase activity was significantly greater (three times) in the perlite inoculated with the recently contaminated soil suspension than with the weathered soil suspension (Fig. 3c, d).

Furthermore, the Kruskal-Wallis statistical analyses indicated significant differences $(p<0.05)$ in the 

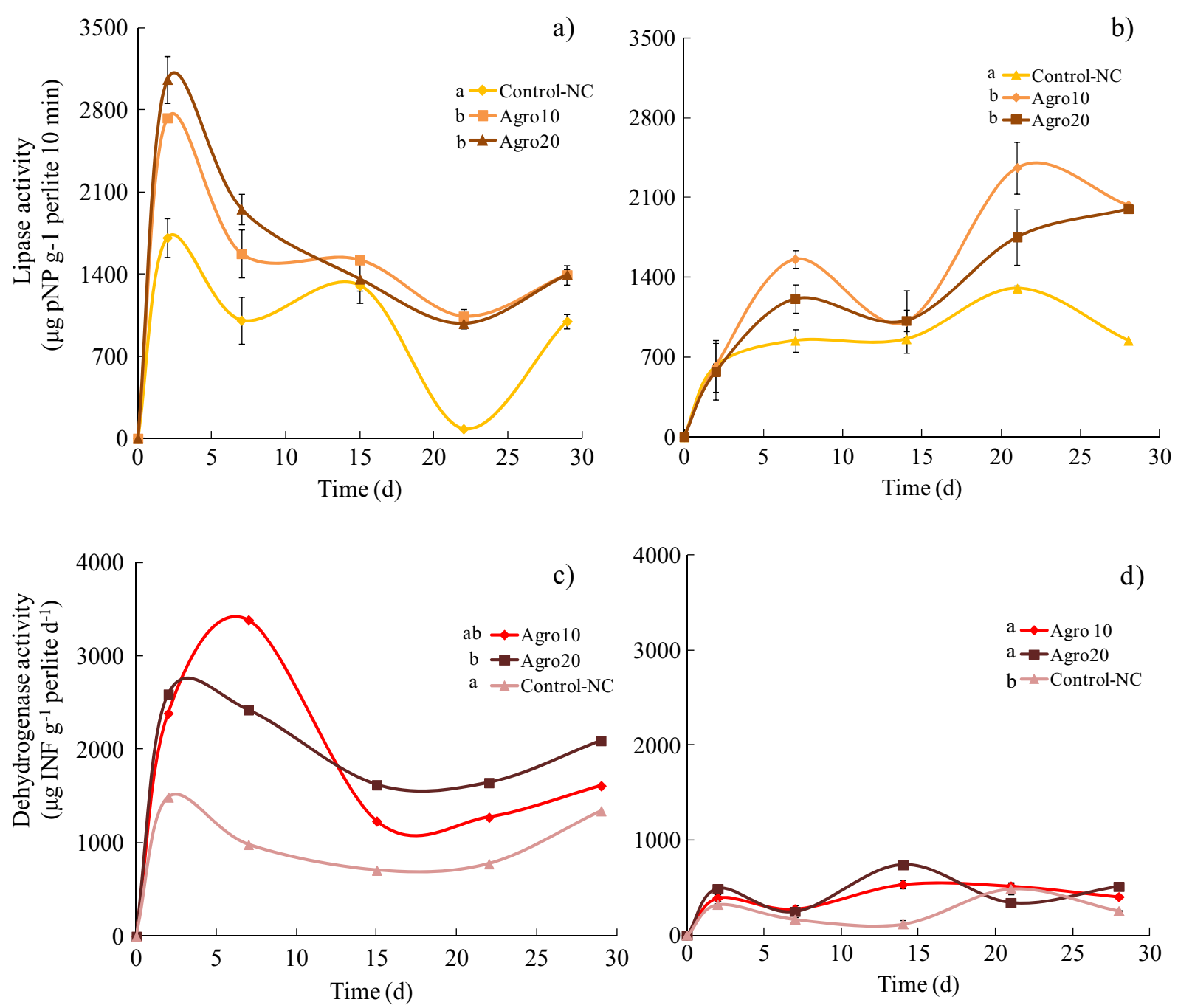

Fig. 3 Lipase and dehydrogenase kinetics recorded in contaminated perlite $\left(0,10,000,20,000 \mathrm{mg} \mathrm{kg}^{-1}\right)$. Lipase activity in the inocula of the recently contaminated soil suspension and the weathered soil suspension is presented in panels (a) and (b).

enzymatic activity among the inocula, with greater values in the RCSS $\left(3388.37 \mu \mathrm{g} \mathrm{INF} \mathrm{g}^{-1}\right)$. With respect to hydrocarbon concentration, the RCSS presented significant differences $(p<0.05)$ among all the treatments $\left(10,000\right.$ and $20,000 \mathrm{mg} \mathrm{kg}^{-1}$, and the control), indicating that the initial concentrations produce an increase in enzymatic activity at a greater concentration. Nonetheless, the WSS presented differences in enzymatic activity between the contaminated perlite $\left(10,000\right.$ and $\left.20,000 \mathrm{mg} \mathrm{kg}^{-1}\right)$ and the control.

Dehydrogenase activity has been linked to the first stages of the aerobic metabolic activity during the biodegradation of different organic compounds,
Dehydrogenase activity in the two inocula is presented in panels (c) and (d). The error bars represent the standard deviation of nine sub-samples for each replicate. The letters $a, a b$ and $b$ indicate the statistical difference between the two inocula $(p<0.05)$

such as aliphatic and aromatic hydrocarbons. This could explain the low activity of this enzyme in the weathered soil, where residual compounds are mostly constituted by heavy fractions like resins and asphaltenes (Díaz-Ramírez et al. 2003; EscalanteEspinosa et al. 2005), instead of medium carbon chain compounds (C10-C18) which typically compose the TPH (light and medium fractions), like those used in the perlite assays. The importance of monitoring and understanding the activity of the oxidoreductases in the soil lies in the fact that processes like mineralisation and organic matter humification are led mainly by oxidation, reduction and 
hydrolysis reactions (Pascual et al. 2000; Van Hamme et al. 2003), processes that are important in the biodegradation of organic compounds, including complex mixtures (TPH).

\section{$4 \mathrm{CO}_{2}$ Production and Hydrocarbon Biodegradation}

Microbial respiratory activity is a good indicator of the biodegradation of organic compounds and substrate mineralisation, as it is linked to microbial growth. A respirometric assay was thus designed to determine the $\mathrm{CO}_{2}$ production rate and the cumulative mineralisation through automated measurements, in closed bottles, with contaminated perlite and RCSS and WSS as inocula.

\subsection{Recently Contaminated Soil Inoculum}

Respirometric profiles for the RCSS are presented in Fig. $4 \mathrm{a}$ and $\mathrm{b}$. The $\mathrm{CO}_{2}$ production rate indicates that the maximum activity took place during the first 15 days of the culture (Fig. $4 \mathrm{a}$ ). The $\mathrm{CO}_{2}$ production rate (mg C$\mathrm{CO}_{2} \mathrm{~kg}^{-1}$ perlite $\mathrm{h}^{-1}$ ) presented a positive correlation between the initial load (0, 10,000 and 20,000 $\left.\mathrm{mg} \mathrm{kg}^{-1}\right)$ of hydrocarbons and the increase in $\mathrm{CO}_{2}$ production rate for the two sources of inocula (Fig. 4a, c). The maximum respiration rate was recorded for the RCSS inoculum $\left(29.16 \pm 0.002 \mathrm{mg} \mathrm{C}-\mathrm{CO}_{2} \mathrm{~kg}^{-1} \mathrm{~h}^{-1}\right)$ on perlite with $\sim 20,000 \mathrm{mg} \mathrm{kg}^{-1}$, while the $\mathrm{CO}_{2}$ production rate was twice lower $\left(12.23 \pm 1.08 \mathrm{mg} \mathrm{C}-\mathrm{CO}_{2} \mathrm{~kg}^{-1} \mathrm{~h}^{-1}\right)$ in the $\sim 10,000 \mathrm{mg} \mathrm{kg}^{-1}$ experimental group (Fig. 4a). The cumulative $\mathrm{CO}_{2}$ production confirmed significant differences $(p<0.05)$ among the mineralisations recorded for the different hydrocarbon concentrations. A short lag stage with a low respiration rate was observed in the presence of the RCSS inoculum. Later, periods of high mineralisation were observed, indicating cyclical periods of biotransformation-oxidation. These results agree with the enzymatic profiles obtained for the same RCSS inoculum (Fig. 3), where the lipase activity recorded maximum levels during the first 10 days of culture.

Attempts to use soil respiration as a criterion to assess respiration in contaminated soils have been carried out in the past. In a study on the scale-up of chemicalbiological remediation techniques applied to a highly contaminated soil, Guzmán-Osorio (2011) reported respiration levels of 0.86 to $2.6 \mathrm{mg} \mathrm{C}-\mathrm{CO}_{2} \mathrm{~kg}^{-1} \mathrm{~h}^{-1}$ of soil after a remediation treatment. Plaza et al. (2005) obtained respiration rates of 8.6 to $38.5 \mathrm{mg} \mathrm{C}-\mathrm{CO}_{2} \mathrm{~kg}^{-1} \mathrm{~h}^{-1}$ during the natural attenuation of hydrocarbon contaminated soils $\left(18,900-172,700 \mathrm{mg} \mathrm{kg}^{-1}\right)$.

Table 3 presents the residual TPH content values obtained during the biodegradation potential assay with the recently contaminated soil and the weathered soil suspension inocula on perlite as solid support. The inocula of the RCSS produced a similar hydrocarbon biodegradation $(\sim 27 \%)$ for the two initial concentrations after 28 days of culture. Escalante-Espinosa et al. (2005) carried out a phytoremediation study with artificially contaminated perlite $\left(5000 \mathrm{mg} \mathrm{kg}^{-1}\right)$ and a microbial consortium as inoculum, and reported a biodegradation of 3 to $12 \%$ for the inoculated and noninoculated treatments (unplanted pots), respectively. In the same experiment, inoculated pots recorded a $75 \%$ of TPH removal after 190 days of experimentation. DíazRamírez et al. (2010) worked with a hydrocarbon (Olmeca crude oil) spiked clay-loam soil and a biostimulation/bioaugmentation trial (30 days of culture), and recorded biodegradation values of 21.65 and $18.09 \%$ for inoculated and non-inoculated treatments, respectively. Zhen-Yu et al. (2012) studied contaminated clay soils $\left(20,000 \mathrm{mg} \mathrm{kg}^{-1}\right)$ inoculated with degrading microorganisms $\left(1 \times 10^{5} \mathrm{CFU} \mathrm{kg}^{-1}\right)$ and reported a biodegradation level of less than $30 \%$ after 20 days of treatment.

\subsection{Weathered Soil Inoculum}

The respirometric kinetics for the WSS are presented in Fig. $4 \mathrm{c}$ and $\mathrm{d}$. The maximum $\mathrm{CO}_{2}$ production rate period was registered between 7 and 12 days of culture in the presence of highly contaminated perlite. A maximum of $14.32 \mathrm{mg} \mathrm{C}-\mathrm{CO}_{2} \mathrm{~kg}^{-1} \mathrm{~h}^{-1}$ was recorded for $10,000 \mathrm{~g} \mathrm{~kg}^{-1}$ of perlite, and $8.30 \mathrm{mg} \mathrm{C}-\mathrm{CO}_{2} \mathrm{~kg}^{-1} \mathrm{~h}^{-1}$ were recorded for $20,000 \mathrm{~g} \mathrm{~kg}^{-1}$ of perlite (Fig. 4c). These values are twice lower than those recorded for the RCSS. Respiratory activity later decreased to almost $3.11 \mathrm{mg} \mathrm{C}-\mathrm{CO}_{2} \mathrm{~kg}^{-1} \mathrm{~h}^{-1}$ in the last week of the culture. The cumulative $\mathrm{CO}_{2}$ production presented a long adaptation stage (first 7 days), after which respiration abruptly increased to around $1470 \mathrm{mg} \mathrm{C}-\mathrm{CO}_{2} \mathrm{~kg}^{-1}(20,000 \mathrm{mg}$ $\left.\mathrm{kg}^{-1}\right), 1184.4 \mathrm{mg} \mathrm{C}-\mathrm{CO}_{2} \mathrm{~kg}^{-1}\left(10,000 \mathrm{mg} \mathrm{kg}^{-1}\right)$ and $360 \mathrm{mg} \mathrm{C}-\mathrm{CO}_{2} \mathrm{~kg}^{-1}$ (non-contaminated perlite) (Fig. 4d). These results are significantly lower $(p<0.05)$ than those recorded for the RCSS. Additionally, more respiration peaks were recorded for 

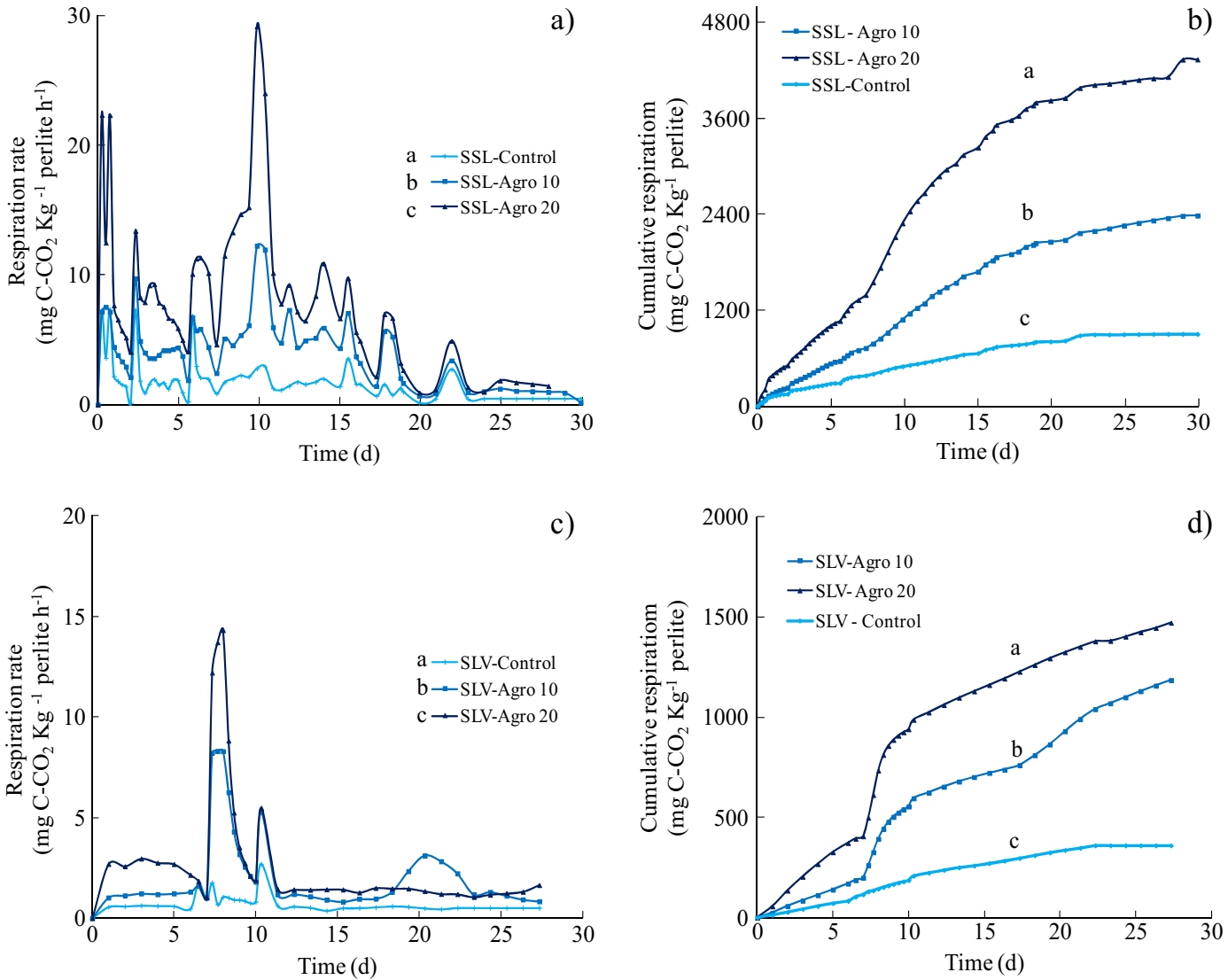

Fig. $4 \mathrm{CO}_{2}$ production rates $\left(\mathrm{mg} \mathrm{C}-\mathrm{CO}_{2} \mathrm{~kg}^{-1}\right.$ perlite $\mathrm{h}^{-1}$ ) and cumulative $\mathrm{CO}_{2}$ production profiles recorded in contaminated perlite $\left(0,10,000,20,000 \mathrm{mg} \mathrm{kg}^{-1}\right)$ inoculated with the recently contaminated soil suspension $(\mathbf{a}, \mathbf{b})$ and the weathered soil

suspension $(\mathbf{c}, \mathbf{d})$. The values represent the standard deviation of three replicates. The letters $a, b$ and $c$ indicate the statistical difference among samples

the bottles inoculated with RCSS (Fig. 4a, c). Despite these results, respiration in the WSS inoculum was greater than that previously reported for this type of

tropical soil (Guzmán-Osorio 2011). These findings indicate that the RCSS has a high capacity to grow on TPH typically composed of $67 \%$ aliphatics, $24 \%$

Table 3 Residual TPH content throughout the biodegradation potential assay using perlite as solid support inoculated with recently contaminated soil (RCSS) and weathered soil (WSS) suspensions

\begin{tabular}{|c|c|c|c|c|}
\hline Time (days) & $\begin{array}{l}\mathrm{SSRC}^{\mathrm{a}} \\
\left(\mathrm{mg} \mathrm{kg}^{-1}\right)\end{array}$ & & $\begin{array}{l}\mathrm{WSS}^{\mathrm{c}} \\
\left(\mathrm{mg} \mathrm{kg}^{-1}\right)^{\mathrm{b}}\end{array}$ & \\
\hline 0 & $15,000 \pm 4,768$ & $22,000 \pm 1618$ & $15,000 \pm 4,769$ & $22,000 \pm 1,618$ \\
\hline 7 & $11,893 \pm 851$ & $19,399 \pm 830$ & $14,704 \pm 805$ & $16,283 \pm 158$ \\
\hline 14 & $12,945 \pm 2,618$ & $16,833 \pm 223$ & $13,104 \pm 592$ & $18,834 \pm 518$ \\
\hline 22 & $12,251 \pm 649$ & $17,134 \pm 173$ & $11,921 \pm 344$ & $15,220 \pm 914$ \\
\hline 29 & $10,873 \pm 796$ & $16,125 \pm 1595$ & $11,563 \pm 618$ & $16,632 \pm 1,570$ \\
\hline Relative TPH loss (\%) & 27.51 & 26.70 & 22.91 & 24.39 \\
\hline
\end{tabular}

${ }^{a}$ Recently contaminated soil suspension inoculum

${ }^{\mathrm{b}}$ Values represent the mean of three replicates

${ }^{\mathrm{c}}$ Weathered soil suspension inoculum 
aromatics and $9 \%$ polars and asphaltenes (DíazRamírez et al. 2003; Gallegos Martínez et al. 2000). In the case of the weathered soil, the lower initial response may reflect an adaptation to a more complex and recalcitrant type of carbon source (such as aged crude oil residues). Based on the relative abundance and the different colony morphology, a greater microbial diversity was observed in the samples inoculated with the RCSS, in comparison with the perlite added to the WSS where less than five predominant morphological types were detected growing on TSA.

It is generally assumed that even if $\mathrm{CO}_{2}$ production is not a direct measure of the volume of oil carbon biotransformation, changes recorded in the microbial activity in oil-contaminated environments reflect a microbial decomposition of the oil (Oh et al. 2002).

Bending et al. (2004) examined the interrelationships among functional biochemical and microbial soil quality indicators, and reported a $\mathrm{CO}_{2}$ respiration rate of 41 to $52 \mathrm{mg} \mathrm{C}-\mathrm{CO}_{2} \mathrm{~kg}^{-1} \mathrm{~h}^{-1}$ for agricultural soils under different management programmes.

Statistical analyses (multifactorial ANOVA) found significant differences in $\mathrm{CO}_{2}$ production $(p<0.05)$ for the factors (a) contamination source (contamination history), (b) hydrocarbon concentration and (c) sampling time. With respect to the soil inocula, the analyses obtained significant differences and indicated that the RCSS inoculum presented the greatest cumulative $\mathrm{CO}_{2}$ production.

\section{Conclusion}

The evaluation of biological indicators and of the biodegradation potential in soils with different contamination histories made it possible to determine a high background microbial activity in these highly contaminated soils. Lipase activity and respiration rates were the best biological indicators, with greater levels than those recorded in non-contaminated soils. The biodegradation efficiency assessing approach based on the estimation of biological indicators (lipase and dehydrogenase activities, and respirometric profiles), in a model system under hydrocarbon bioavailability conditions, showed that the recently contaminated soil was the most active. The profiles of lipase and dehydrogenase microbial activity indicated a highly oxidative initial stage, even duplicating the levels of produced $\mathrm{CO}_{2}$ with respect to the weathered soil inoculum. A positive correlation was obtained for hydrocarbon biodegradation and lipase activity in the two inocula. Samples from the recently contaminated site presented a high potential for the microbial biodegradation of the hydrocarbons spilled at the site. The protocols developed in this study may help to characterise contaminated sites, apply monitored natural attenuation programmes and select bioremediation strategies to be applied to weathered and recently contaminated tropical soils.

Acknowledgments This study was financed by the Mexican National Science and Technology Council (CONACyT) Project No. 181371. J. Riveroll-Larios received a grant from CONACyT (No. 417327). The authors thank Mercedes Fuentes Velasco for reviewing the manuscript and Barbara Joos for technical assistance in setting up the respirometry system.

Open Access This article is distributed under the terms of the Creative Commons Attribution 4.0 International License (http:// creativecommons.org/licenses/by/4.0/), which permits unrestricted use, distribution, and reproduction in any medium, provided you give appropriate credit to the original author(s) and the source, provide a link to the Creative Commons license, and indicate if changes were made.

\section{References}

Acosta, Y., \& Paolini, J. (2005). Dehydrogenase enzymatic activity in Calcicorthids soil emmended with organic residues. Agronomía Tropical., 55(2), 217-232.

Adams, R. H., Guzmán-Osorio, F. J., \& Zavala Cruz, J. (2008). Water repellency in oil contaminated sandy and clayed soils. International Journal of Environmental Science Technology., 5(4), 445-454.

Adams, R. H., Castillo-Acosta, O., Escalante-Espinosa, E., \& Zavala-Cruz, J. (2011). Natural attenuation and phytoremediation of petroleum hydrocarbon impacted soil in tropical wetland environments. In L. G. Torres \& E. R. Bandala (Eds.), Remediation of soils and aquifers (pp. 1-24). New York: Nova Publishers.

Adams, R. H., Olán-Castro, D., Guzmán-Osorio, F. J., \& DíazRamírez, I. J. (2009). Relationship between geomorphology and contamination with weathered hydrocarbons in an old river levee/marsh association. International Journal of Environmental Science Technology., 6(4), 527-538.

Adams, R.H., Guzmán-Osorio, F.J., Díaz-Ramírez, I.J., Domínguez-Rodríguez, V.I., Álvarez-Coronel, G. (2012). Impact and recovery of a coastal river system: characterization of Rio Chiquito, Veracruz after the 2007 oil spill. In: Sánchez, A.J., Chiappa-Carrara, X., Brito, R. (Eds). Recursos Costeros del Sureste. Volumen II. 548-580. RECORECOS, Tabasco, México.

Bending, G.D., Turner, M.K., Rayns, F., Marx, M-C., Wood, M. (2004). Microbial and biochemical soil quality indicators and their potential for differentiating areas under contrasting 
agricultural management regimes. Soil Biology and Biochemistry. (36), 1785-1792.

Chang, W., Dyen, M., Spagnuolo, L., Simon, P., Whyte, L., Ghoshal, S. (2010). Biodegradation of semi- and nonvolatile petroleum hydrocarbons in aged, contaminated soils from a sub-Arctic site: laboratory pilot-scale experiments at site temperatures. Chemosphere. (80), 319-326.

Cram, S., Siebe, C., Ortíz-Salinas, R., \& Herre, A. (2004). Mobility and persistence of petroleum hydrocarbons in peat soils of southeastern Mexico. Soil Sediment Contamination., 13(5), 341-360.

Díaz-Ramírez, I., Escalante-Espinosa, E., Adams Schroeder, R., Fócil-Monterrubio, R., Ramírez-Saad, H. (2013). Hydrocarbon biodegradation potential of native and exogenous microbial inocula in Mexican tropical soils. In: Chamy, R., Rosenkranz, F. (Eds). Biodegradation of hazardous and special products. 155-178, In: Tech, Rijeka, Croatia.

Díaz-Ramírez, I. J., Escalante-Espinosa, E., Favela-Torres, E., Gutiérrez-Rojas, M., \& Ramírez-Saad, H. (2008). Design of bacterial defined mixed cultures for biodegradation of specific crude oil fractions, using population dynamics analysis by DGGE. International Biodeterioration and Biodegradation., 2(6), 21-30.

Díaz-Ramírez, I.J., Gutiérrez-Rojas, M., Ramírez-Saad, H., FavelaTorres, E. (2003). Biodegradation of Maya crude oil fractions by bacterial strains and a defined mixed culture isolated from Cyperus laxus rhizosphere soil in a contaminated site. Canadian Journal of Microbiology. (49), 755-761.

Díaz-Ramírez, I.J., Priego-Rangel, S., Torres-Colorado, J., Aguirre-Marín, D.I., Escalante-Espinoza, E. (2010). Microbial activity during application of different bioremediation treatments in Olmeca crude oil contaminated soil. II Congreso de la Sociedad Latinoamericana de Biotecnología Ambiental y Algal, Cancún, México. Publishing Physics Web. http://www3.inecol.edu.mx/solabiaa/ARCHIVOS/ documentos/congresos/2010-solabiaa/Memorias_II_ Congreso_2010.pdf.

Escalante-Espinosa, E., Gallegos-Martínez, M.E., Favela-Torres, E., Gutiérrez-Rojas, M. (2005). Improvement of the hydrocarbon phytoremediation rate by Cyperus laxus Lam. inoculated with a microbial consortium in a model system. Chemosphere. (59), 405-413.

Gallegos Martínez, M., Gómez Santos, A., González Cruz, L., Montes de Oca García, M.A., Yáñez Trujillo, L., Zermeño Eguía Lis, J.A., Gutiérrez-Rojas, M. (2000). Diagnostic and resulting approaches to restore petroleum-contaminated soil in a Mexican tropical swamp. Water Science Technology. $42(5,6), 377-384$.

Guzmán-Osorio, F.J. (2011). Industrial scale-up of the chemicalbiological stabilization for remediation of hydrocarbon contaminated soil. Environmental Science Master's Thesis. Universidad Juárez Autónoma de Tabasco, Mexico.

Hasan, F., Shah, A. A., \& Hameed, A. (2009). Methods for detection and characterization of lipases: a comprehensive review. Biotechnology Advances, 27(6), 782-798.

Joseph, B., Ramteke, P.W., Thomas, G. (2008). Cold active microbial lipases: some hot issues and recent developments. Biotechnology Advances. (26), 457-470.

Klee, A. J. (1996). Most probable number calculator. Version 4.04. Risk reduction engineering laboratory. Cincinnati, Ohio: United States Environmental Protection Agency.
Liu, G. P. W., Chang, T. C., Whang, L. M., Kao, C. H., Pan, P. T., $\&$ Cheng, S. S. (2011). Bioremediation of petroleum hydrocarbon contaminated soil: effects of strategies and microbial community shift. International Biodeterioration and Biodegradation, 65(8), 1119-1127.

Lorch, H.-J., Benckieser, G., \& Ottow, J. C. G. (1995). Basic methods for counting microorganisms in soil and water. In K. Aleff \& P. Nannipieri (Eds.), Methods in applied soil microbiology and biochemistry (pp. 146-161). Great Britain: Academic Press.

Maila, M.P., Cloete, T.E. (2005). The use of biological activities to monitor the removal of fuel contaminants-perspective for monitoring hydrocarbon contamination: a review. International Biodeterioration and Biodegradation. (55), $1-8$.

Maletić, S. P., Dalmacija, B. D., Rončević, S. D., Agbaba, J. R., \& Ugarčina, P. S. D. (2011). Impact of hydrocarbon type, concentration and weathering on its biodegradability in soil, part A. Journal of Environmental Science and Health, 46, $1042-1049$

Margesin, R. (2005). Determination of enzyme activities in contaminated soil. In: Margesin, R., Schinner, F. (Eds). Manual for soil analysis-monitoring and assessing soil bioremediation. Soil Biology, Springer, Germany. (5), 309-313, 316319.

Margesin, R., \& Schinner, F. (2001). Bioremediation (natural attenuation and biostimulation) of diesel-oil-contaminated soil in an alpine glacier skiing area. Applied Environmental Microbiology., 67(7), 3127-3133.

Margesin, R., Zimmerbauer, A., \& Schinner, F. (2000). Monitoring of bioremediation by soil biological activities. Chemosphere, 40, 339-346.

Margesin, R., Hämmerle, M., Tscherko, D. (2007). Microbial activity and community composition during bioremediation of diesel-oil-contaminated soil: effects of hydrocarbon concentration, fertilizers, and incubation time. Microbial Ecology. (53), 259-26.

Medina-Moreno, S. A., Jiménez-Islas, D., Gracida-Rodríguez, J. N., Gutiérrez-Rojas, M., \& Díaz-Ramírez, I. J. (2011). Modeling rhamnolipids production by Pseudomonas aeruginosa from an immiscible carbon source in a batch system. International Journal of Environmental Science Technology., 8(3), 471-482.

Mirás Avalos, J.M., Sande Fouz, P., Vidal Vázquez, E. (2007). Soil dehydrogenase activity on two topographical positions of a cultivated soil. Cuadernos Lab. Xeolóxico de Laxe, Coruña. (32), 151-163.

Neto, M., Ohannessian, A., Delolme, C., \& Bedell, J. P. (2007). Towards an optimized protocol for measuring global dehydrogenase activity in storm-water sediments. Research Articles., 7(2), 101-110.

NOM-021-SEMARNAT-2000. Norma Oficial Mexicana. Specifications of soil fertility, salinity, sampling and analysis.

NOM-138-SEMARNAT/SS-2003. Norma Oficial Mexicana. Permissible maximum limits of hydrocarbons in soils and specifications for characterization and remediation.

Oh, Y.-S., Choi, W.-Y., Lee, Y.-H., Choi, S.-C., Kim, S.-J. (2002). Biological treatment of oil-contaminated sand: comparison of oil degradation based on thin-layer chromatography/flame ionization detector and respirometric analysis. Biotechnology Letters. (22), 595-598. 
Pascual, J.A., García, C., Hernández, T., Moreno, J.L., Ros, M. (2000). Soil microbial activity as a biomarker of degradation and remediation processes. Soil Biology and Biochemistry. (32), 1877-1883.

Pérez-Cadena, R. (2010). Isolation of bacterial strains present in total hydrocarbon petroleum contaminated soils and their kinetics characterization of aromatics compounds biodegradation and biosurfactants biosynthesis. Master's Thesis, Polytechnic University of Pachuca, Mexico

Plaza, G., Nalecz-Jawecki, G., Ulfig, K., Brigmon, R.L. (2005). The application of bioassays as indicators of petroleumcontaminated soil remediation. Chemosphere. (59), 289-296.

Riffaldi, R., Levi-Minzi, R., Cardelli, R., Palumbo, S., Saviozzi, A. (2006). Soil biological activities in monitoring the bioremediation of diesel oil-contaminated soil. Water, Air and Soil Pollution. (170), 3-15.

Sánchez, B., Ruíz, M., \& Ríos, M. (2005). Organic matter and biological activity in soil in relation to altitude, in the basin of the river Maracay, Aragua State. Agronomía Tropical., 55(4), 507-534.

Sirisha, E., Rajasekar, N., \& Lakshmi Narasu, M. (2010). Isolation and optimization of lipase producing bacteria from oil contaminated soils. Advances in Biological Research., 4(5), 249252.

Supaphol, S., Panichsakpatana, S., Trakulnaleamsai, S., Tungkananuruk, N., Roughjanajirapa, P., O’Donnell, A.G. (2005). The selection of mixed microbial inocula in environmental biotechnology: example using petroleum contaminated tropical soils. Journal of Microbiological Methods. (65), 432-441.

Van Hamme, J.D., Singh, A., Ward, O.P. (2003). Recent advances in petroleum microbiology. Microbiology and Molecular Biology Reviews. 67:4:50.

Von Mersi, W., Schinner, F. (1991). An improved and accurate method for determining the dehydrogenase activity of soils with iodonotrotetrazolium chloride. Biology and Fertility of Soils. (11), 216-220.

Vyas, T. K., \& Dave, B. P. (2011). Production of biosurfactant by Nocardia otitidiscaviarum and its role in biodegradation of crude oil. International Journal of Environmental Science Technology., 8(2), 425-432.

Wrenn, B.A., Venosa, A.D. (1996). Selective enumeration of aromatic and aliphatic hydrocarbon degrading bacteria by a most-probable-number procedure. Canadian Journal of Microbiology. (42), 252-258.

Zavala, C. J., Gavi, R. F., Adams, S. R. H., Ferrera-Cerrato, R., Palma-López, J. D., Vaquera, H. H., \& Domínguez, E. M. (2005). Derrames de petróleo en suelos y adaptación de pastos tropicales en el activo Cinco Presidentes, Tabasco. Terra Latinoamericana., 23(2), 293-302.

Zhen-Yu, W., Ying, X., Hao-Yung, W., Jian, Z., Gong.Mei, G., Feng-Min, L., Xing, B. (2012). Biodegradation of crude oil in contaminated soils by free and immobilized microorganisms. Pedosphere. 22(5), 717-725 